\title{
PENGARUH KEDISIPLINAN DAN GAJI KARYAWAN TERHADAP KINERJA KARYAWAN DI UPK KECAMATAN TURI
}

\author{
*(Evi Fitrotun Najiah \\ Fakultas Ekonomi \\ Universitas Islam Lamongan
}

\begin{abstract}
ABSTRAK
Kedisiplinan dan gaji karyawan merupakan hal penting dan mempunyai peranan dalam meningkatkan kinerja karyawan menuju keberhasilan suatu instansi karena jika karyawan memiliki sikap disiplin maka kinerja karyawan memuaskan. Pemberian gaji dan insentif sangat penting karena untuk menumbuhkan semangat karyawan dalam kinerjanya. Rumusan masalah dalam jurnal ini adalah untuk mengetahui apakah kedisiplinan dan gaji karyawan mempunyai pengaruh secara parsial, secara simultan dan pengaruh paling dominan terhadap kinerja karyawan di UPK (Unit Pengelola Kegiatan) Kecamatan Turi. Berdasarkan hasil penelitian dapat disimpulkan bahwa kedisiplinan dan gaji karyawan secara parsial berpengaruh positif dan signifikan terhadap kinerja karyawan di UPK Kecamatan Turi. Instansi harus mampu menerapkan kedisiplinan dan gaji karyawan yang tepat untuk meningkatkan kinerja karyawan di UPK Kecamatan Turi.
\end{abstract}

Kata Kunci : Kedisiplinan, Gaji Karyawan, dan Kinerja Karyawan.

\section{PENDAHULUAN}

Manajemen Sumber Daya Manusia merupakan bagian dari fungsi manajemen, maka sebelum mengemukakan pendapat-pendapat mengenai apa yang dimaksud dengan manajemen sumber daya manusia, perlu dijelaskan mengenai arti manajemen itu sendiri.

Menurut Sadili Samsudin (2010:22) menyatakan bahwa "Manajemen Sumber Daya Manusia merupakan suatu kegiatan pengelolaan yang meliputi pendayagunaan, pengembangan, penilaian, pemberian balas jasa bagi manusia sebagai individu anggota organisasi atau perusahaan bisnis."

Sumber daya manusia merupakan salah satu unsur input sama dengan unsur input lainnya seperti modal, mesin, bahan mentah dan teknologi yang diubah melalui proses produksi menjadi output berupa barang atau jasa. Manajemen sumber daya manusia merupakan bagian dari manajemen, dimana manajemen sumber daya manusia ini menitikberatkan perhatiaannya pada masalah-masalah manusia dalam hubungan kerja dengan tugastugasnya tanpa mangabaikan faktorfaktor produksi lainnya.

Tugas manajemen sumber daya manusia yang paling penting adalah mengatur dan mengelola faktor manusia seoptimal mungkin agar dapat diperoleh hasil yang efektif dan efisien dengan jalan menyusun, mengembangkan, dan melaksanakan program pembangunan sumber daya manusia sesuai dengan kebutuhan perusahaan. Menurut Hamzah dan Nina (2014:87) Manajemen Kinerja adalah suatu 
pendekatan stratejik dan terintegrasi untuk menghasilkan keberhasilan yang berkelanjutan bagi bekerja di dalam organisasi dan dengan mengembangkan kapabilitas tim dan individu pemberi kontribusi.

Dalam efektivitas kinerja karyawan kedisiplinan karyawan merupakan hal utama yang harus diperhatikan dalam bekerja. Karena jika karyawan disiplin maka kinerja karyawan memuaskan, sedangkan jika tidak disiplin maka kinerja karyawan mengalami kemunduran. Seperti halnya di UPK Kecamatan Turi. kedisiplinan karyawan dapat dilihat dari absensi dan kinerja saat mengerjakan administrasi UPK. Jika karyawan datang lebih awal maka perkerjaan akan cepat terselesaikan dan jika datang telat maka pekerjaanpun terbengkelai. Dalam hal absensi, UPK paling lambat pukul 08.00 WIB.

Kinerja Karyawan tak hanya dipengarungi oleh kedisiplinan saja tetapi pemberian gaji dan insentif dalam rangka meningkatkan kinerja adalah suatu aspek dari manajemen sumber daya manusia untuk meningkatkan kinerja karyawan secara efektif dan efisien. Pemberian gaji dan insentif sangat penting karena untuk menumbuhkan semangat karyawan dalam kinerjanya. Sedangkan jika tidak diberi gaji dan insentif maka karyawan akan malas dalam bekerja. (Handoko, 2012:155)

Berdasarkan uraian di atas maka penulis mengambil jurnal dengan judul "Pengaruh Kedisiplinan dan Gaji Karyawan Terhadap Efektivitas Kinerja Karyawan di UPK Kecamatan Turi “.

Tujuan penelitian ini adalah yang hendak dicapai dalam penelitian ini adalah untuk mengetahui apakah kedisiplinan dan gaji karyawan mempunyai pengaruh secara parsial terhadap kinerja karyawan di UPK Kecamatan Turi. Untuk mengetahui apakah kedisiplinan dan gaji karyawan mempunyai pengaruh secara simultan terhadap kinerja karyawan di UPK Kecamatan Turi. Untuk mengetahui dan menganalisis manakah di antara Kedisiplinan dan Gaji Karyawan yang mempunyai pengaruh paling dominan terhadap kinerja karyawan di UPK Kecamatan Turi .

Definisi Manajemen Menurut Appley dan Oey Liang Lee (2010:16) manajemen adalah seni dan ilmu, dalam manajemen terdapat strategi memanfaatkan tenaga dan pikiran orang lain untuk melaksanakan suatu aktifitas yang diarahkan pada pencapaian tujuan yang telah ditentukan sebelumnya. Dalam manajemen terdapat teknikteknik yang kaya dengan nilai-nilai estetika kepemimpinan dalam mengarahkan, memengaruhi, mengawasi, mengorganisasikan semua komponen yang saling menunjang untuk tercapainya tujuan yang dimaksudkan.

Sedangkan menurut Terry (2010:16) menjelaskan bahwa manajemen merupakan suatu proses khas yang terdiri atas tindakantindakan perencanaan, pengorganisasian, penggerakan, dan pengendalian untuk menentukan serta mencapai tujuan melalui pemanfaatan sumber daya manusia dan sumber daya lainnya.

Jadi dapat disimpulkan bahwa manajemen adalah suatu proses yang terdiri dari perencanaan, pengorganisasian, pengarahan, dan pengawasan melalui pemanfaatan sumber daya dan sumber-sumber 
lainnya secara efektif dan efisien untuk mencapai tujuan tertentu.

Definisi Sikap terhadap pekerjaan menurut Hamzah dan Nina (2014:108) menjelaskan bahwa sikap terhadap pekerjaan yakni kesukaan akan kerja dibandingkan dengan kegiatan lain, seperti bersantai atau semata-mata memperoleh kepuasan dan kesibukan pekerjaannya sendiri, atau merasa terpaksa melakukan sesuatu hanya untuk kelangsungan hidupnya. Indikator dari sikap terhadap pekerjaan tersebut, yaitu kerja adalah hukuman, kerja adalah kewajiban, kerja adalah sumber penghasilan, kerja adalah kesenangan, kerja adalah gengsi, kerja adalah aktualisi diri, kerja adalah panggilan jiwa, kerja adalah pengabdian terhadap sesama, kerja adalah hidup, kerja adalah ibadah, dan kerja adalah suci.

Kedisiplinan adalah kesadaran dan kesediaan seseorang menaati semua peraturan perusahaan dan norma-norma social yang berlaku (Hasibuan, 2012:193).

Kedisiplinan harus ditegakkan dalam suatu organisasi perusahaan. Tanpa dukungan disiplinkaryawan yang baik, sullit perusahaan untuk mewujudkan tujuannya. Jadi, kedisiplinan adalah kunci keberhasilan suaru perusahaan dalam mencapai tujuannya. Indikatorindikator Kedisiplinan adalah Kehadiran, Disipilin Jam Kerja, dan Administrasi.

Gaji adalah suatu bentuk balas jasa ataupun penghargaan yang diberikan secara teratur kepada seorang pegawai atas jasa dan hasil kerjanya. Gaji sering juga disebut sebagai upah, dimana keduanya merupakan suatu bentuk kompensasi, yakni imbalan jasa yang diberikan secara teratur atas prestasi kerja yang diberikan kepada seorang pegawai. Perbedaan gaji dan upah hanya terletak pada kuatnya ikatan kerja dan jangka waktu penerimaannya. Seseorang menerima gaji apabila ikatan kerjanya kuat, sedang seseorang menerima upah apabila ikatannya kerjanya kurang kuat. Dilihat dari jangka waktu penerimaannya, gaji pada umumnya diberikan pada setiap akhir bulan, sedang upah diberikan pada setiap hari ataupun setiap minggu. Dalam hal ini, pengertian gaji untuk seterusnya disebut sebagai gaji pokok.

Besarnya gaji pokok yang diberikan kepada seorang karyawan, biasanya sangat tergantung dengan latar belakang pendidikan yang dimiliki, kemampuan maupun pengalaman kerjanya.

Tunjangan adalah unsur-unsur balas jasa yang diberikan dalam nilai rupiah secara langsung kepada karyawan individual dan dapat diketahui secara pasti. Tunjangan diberikan kepada karyawan dimaksud agar dapat menimbulkan /meningkatkan semangat kerja dan kegairahan bagi para karyawan.

Setiap karyawan yang bekerja diluar jam kerja ataupun karyawan yang bekerja pada hari-hari libur, ataupun karyawan yang memiliki jam-kerja lebih besar dari 8 jam dalam sehari, maka sesuai dengan peraturan pemerintah, karyawan yang bersangkutan berhak untuk menerima tunjangan lembur. Besarnya tunjangan lembur ini sangatlah bervariasi, tetapi biasanya setiap perusahaan sudah memiliki peraturan tersendiri yang mengatur secara khusus mengenai besarnya tunjangan lembur setiap karyawan yang mereka miliki. Karyawan bagian pemasaran biasanya tidak 
memiliki fasilitas yang berupa tunjangan lembur, karena prestasi mereka diukur berdasar omzet penjualan yang mereka hasilkan. sebagai gantinya, biasanya mereka akan mendapat bonus yang besarnya sesuai dengan apa yang mereka hasilkan kepada perusahaan.

Kasbon merupakan suatu fasilitas yang bisa digunakan oleh para karyawan untuk mengambil sebagian gaji yang akan diterimanya terlebih dahulu. Pada saat akhir bulan, gaji karyawan tersebut akan dipotong sesuai dengan jumlah kasbon yang ada. Pembayaran kasbon biasanya dilakukan pada saat akhir bulan, yaitu pada saat yang bersangkutan menerima gaji.

Besarnya gaji pokok ataupun tunjangan yang diberikan kepada karyawan, pada saat-saat tertentu akan di-evaluasi. Ada kemungkinan bahwa besarnya tunjangan ataupun fasilitas yang diberikan kepada karyawan, akan mengalami penurunan. Hal ini disebabkan karyawan yang bersangkutan mungkin sudah tidak menjabat pada posisi tersebut, sehingga karyawan yang bersangkutan tidak berhak lagi untuk menerimanya.

Dengan demikian, selain menerima gaji pokok yang besarnya telah ditentukan, pada umumnya setiap karyawan juga akan menerima berbagai macam tunjangan serta dikurangi dengan berbagai macam kewajiban yang harus dibayarkan kepada perusahaan. Secara umum dapatlah dikatakan, bahwa komponen gaji yang diterima seseorang, pada umumnya terdiri atas: Gaji Pokok + Aneka Tunjangan - Aneka Potongan.

Menurut Suwatno (2011:196) "kinerja atau prestasi kerja merupakan hasil yang dicapai seseorang menurut ukuran yang berlaku, dalam kurun waktu tertentu, berkenaan dengan pekerjaan serta perilaku dan tindakanya. Kinerja dapat diartikan "sebagai suatu hasil dari usaha seseorang yang dicapai dengan adanya kemampuan dan perbuatan dalam situasi tertentu." Dari beberapa pengertian di atas maka dapat disimpulkan bahwa kinerja karyawan merupakan hasil kerja seseorang baik secara kualitas maupun kuantitas berdasarkan tanggung jawab yang telah dibebankan kepada karyawan. Indikator-Indikator Kinerja adalah Kedisiplinan, Kualitas, dan Loyalitas.

Berdasarkan pengertian di atas, penulis menarik kesimpulan bahwa kinerja merupakan kualitas dan kuantitas dari suatu hasil kerja (output) individu maupun kelompok dalam suatu aktivitas tertentu yang diakibatkan oleh kemampuan yang diperoleh dari proses belajar serta keinginan untuk berprestasi.

\section{METODE PENELITIAN}

Adapun waktu yang digunakan oleh penulis dalam melakukan penelitian badalah mulai dari bulan Januari sampai dengan bulan Juni 2016. Sedangkan lokasi penelitian adalah UPK Kecamatan Turi Jl. Kepatihan Kecamatan Turi.

Jenis penelitian ini adalah penelitian kuantitatif. Menurut Sugiyono (2012:7) metode penelitian kuantitatif dapat diartikan sebagai metode penelitian yang berlandaskan pada filsafat positivisme, digunakan untuk meneliti pada populasi atau sampel tertentu. Teknik pengambilan sampel pada umumnya dilakukan secara random, pengumpulan data menggunakan instrumen penelitian, analisis data bersifat 
kuantitatif/statistik dengan tujuan untuk menguji hipotesis yang telah ditetapkan Metode kuantitatif sering juga disebut metode tradisional, positivistik, ilmiah/scientific dan metode discovery. Metode kuantitatif dinamakan metode tradisional, karena metode ini sudah cukup lama digunakan sehingga sudah mentradisi sebagai metode untuk penelitian. Metode ini disebut sebagai metode positivistik karena berlandaskan pada filsafat positivisme. Metode ini disebut sebagai metode ilmiah (scientific) karena metode ini telah memenuhi kaidah-kaidah ilmiah yaitu konkrit, empiris, obyektif, terukur, rasional dan sistematis. Metode ini juga disebut metode discovery karena dengan metode ini dapat ditemukan dan dikembangkan berbagai iptek baru. Metode ini disebut metode kuantitatif karena data penelitian berupa angka-angka dan analisis menggunakan statistik.

Populasi adalah wilayah generalisasi yang terdiri dari atas : obyek / subyek yang mempunyai kualitas dan karakteristik tertentu yang ditetapkan oleh peneliti untuk dipelajari dan kemudian ditarik kesimpulannya. Jadi populasi bukan hanya orang, tetapi juga obyek dan benda - benda alam yang lain. Populasi juga bukan sekedar jumlah yang ada obyek / subyek yang dipelajari, tetapi meliputi seluruh karakteristik atau sifat yang dimiliki oleh subyek atau obyek itu (Sugiyono, 2013:117). Dalam penelitian ini populasi yang digunakan adalah aktivitas semua karyawan UPK Kecamatan Turi. Sampel adalah bagian dari jumlah dan karakteristik yang dimiliki oleh populasi tersebut. Bila populasi besar dan peneliti tidak mungkin mempelajari semua yang ada pada populasi, misalnya karena keterbatasan dana, tenaga dan waktu, maka peneliti dapat menggunakan sampel yang diambil dari populasi itu (Sugiyono, 2012:118). Sampel yang diambil dalam penelitian ini adalah karyawan UPK Kecamatan Turi dan data gaji tahun 2011-2015. Teknik sampling adalah teknik pengambilan sampel untuk menentukan sampel apa yang digunakan dalam penelitian, terdapat berbagai teknik sampling yang digunakan. Dalam penelitian ini teknik sampling yang digunakan adalah purposive sampling yaitu teknik pengambilan sampel yang dilakukan karena beberapa pertimbangan , mislanya alasan keterbatasan waktu, tenaga, dan dana sehingga tidak dapat diambil sampel yang besar dan jauh. (Arikunto, 2013:183).

Adapun prosedur pengumpulan data yang dilakukan penulis dalam penyusunan skripsi ini menggunakan beberapa metode antara lain : Library Study (Studi Kepustakaan) Yaitu studi pustaka yang dilakukan dengan mempelajari literature - literature yang berkaitan dengan judul skripsi. Field Research (Studi Lapangan) Yaitu metode penelitian dengan terjun langsung pada obyek yang diteliti dilapangan untuk mendapatkan data secara nyata. Penulis lakukan dengan cara : Kuesioner merupakan teknik pengumpulan data yang dilakukan dengan cara memberi seperangkat pertanyaan atau pernyataan tertulis kepada responden (Sugiyono, 2013:199). Dalam penelitian ini penulis menyebarkan kuesioner kepada responden karyawan UPK Kecamatan Turi. Observasi Yaitu cara pengumpulan data dengan jalan pengamatan secara langsung 
terhadap obyek yang diselidiki mengadakan pencatatan seperlunya (Sugiyono, 2013:204). Dalam penulisan skripsi ini, data di peroleh melalui kuesioner kepada karyawan. Hasil pengumpulan data ini untuk memperoleh pendapat responden terhadap penyatuan - penyatuan yang ada di dalam kuisioner. Setelah data terkumpul, selanjutnya dilakukan proses penyaringan data yang sesuai dengan kebutuhan penelitian.

Variabel bebas adalah variabel yang menjadi sebab timbulnya atau berubah variabel terikat (devenden variabel) (Sugiyono, 2012:3). Jadi Variabel bebas adalah variabel yang mempengaruhi. Pada penelitian ini, yang dimaksud dengan variabel bebas adalah faktor sengaja dimunculkan, dimanipulasi dan diukur oleh peneliti dan dikenakan pada kelompok eksperimen yang diteliti. Kedisiplinan (X1) adalah suatu kondisi yang tercipta dan terbentuk melalui proses dari serangkaian perilaku yang menunjukkan nilai-nilai ketaatan. Gaji Karyawan (X2) adalah balas jasa atas faktor produksi tenaga kerja yang tidak dipengaruhi oleh produksi atau pembayaran atas penyerahan jasa yang dilakukan oleh para karyawan.

Variabel terikat merupakan variabel yang dipengaruhi atau yang menjadi akibat karena adanya variabel bebas (Sugiyono, 2012:3). Pada penelitian ini, yang dimaksud variabel terikat adalah keluaran yang terjadi karena pengaruh variabel bebas. Kinerja Karyawan (Y) adalah suatu proses dimana karyawan melakukan tugas dengan baik sesuai dengan bidangnya dan juga sesuai dengan aturan instansi atau lembaga untuk mempertanggungjawabkan tugas - tugasnya.

ada 4 tipe pokok dari skala sikap yaitu : skala Likert, skala Thurstone, skala Guttman dan skala semantik deferensial. Dalam penelitian ini skala yang digunakan adalah skala Likert.

Skala Likert (Method of Summated Rating) digunakan untuk mengukur sikap, pendapat, dan persepsi dari individu atau kelompok tentang fenomena sosial. Fenomena sosial ini disebut variabel penelitian yang telah ditetapkan secara spesifik oleh peneliti. Jawaban dari setiap instrumen yang mengguakan skala Likert mempunyai gradasi dari sangat positif sampai sangat negatif yag dapat berupa kata-kata antara lain : sangat setuju, setuju, ragu-ragu, tidak setuju, sangat tidak setuju, selalu, sering, kadang-kadang, tidak pernah. Instrumen penelitian yang menggunakan skala Likert dapat dibuat dalam bentuk centang (checklist) ataupun pilihan ganda.

Untuk membatasi masalah yang dihadapi, peneliti mengadakan teknik analisa dengan menggunakan analisa sebagai berikut : Uji Validitas, Uji Reliabilitas, Regresi Berganda, Koefisien Determinasi, Uji t, dan Uji F.

\section{PEMBAHASAN}

Dari uji validitas diketahui $r$ tabel sebesar 0,254 ( $\mathrm{df}=\mathrm{N}-2$ dan probabilitasnya 0,05$)$, Uji validitas indikator $X_{1}, 1=0,707, X_{1}, 2=0,868$, $X_{1}, 3=0,796$ indikator $X_{2}, 1=0,713$, $X_{2}, 2=0,839, X_{2}, 3=0,890$ sedangkan indikator $\mathrm{Y}_{1}=0,718, \quad \mathrm{Y}_{2}=0,757$, $\mathrm{Y}_{3}=0,770$. Dari hasil diatas menunjukan semua instrument valid, Hasil korelasi $r$ menunjukan semua instrumen lebih besar dari 0,198. 
Dari uji reliabilitas diketahui nilai Crobach Alpha lebih besar dari 0,60 , dan diketahui hasil uji reliabilitas indikator $\mathrm{X}_{1}=0,819, \mathrm{X}_{2}=$ 0,832 dan indikator $\mathrm{Y}=0,797$ menunjukan semua variabel mempunyai koefisien alpha yang lebih besar dari 0,60 sehingga dapat dikatakan bahwa masing-masing variabel adalah reliabel.

Dari uji koefisien determinasi dapat diketahui bahwa koefisien determinasi ( $R$ Square ) yang diperoleh sebesar 0,179 , hal ini berarti $17,9 \%$ variabel dependen yaitu Kinerja Karyawan dapat dijelaskan oleh variabel independennya yaitu Kedisiplinan dan Gaji Karyawan. serta sisanya $82,1 \%$ dijelaskan oleh variabel lain yang tidak diajukan dalam penelitian ini.

Dari uji regresi linier berganda didapatkan suatu persamaan regresi sebagai berikut : $\mathrm{Y}=9,502+0,166 \mathrm{X}_{1}$ $+0,065 \mathrm{X}_{2}$

$\mathrm{a}=9,502$, merupakan konstanta yang berarti bahwa apabila variabel bebas (Kedisiplinan dan Gaji ) pengaruhnya $=0$ maka hasil dari Kinerja Karyawan yang diperoleh adalah sebesar 9,502. $\mathrm{b}_{1}=0,166$ artinya variabel kedisiplinan mempunyai pengaruh yang positif terhadap Kinerja Karyawan, Hal ini menunjukkan bahwa jika penilaian karyawan terhadap kedisiplinan naik sebesar 1 poin maka Kinerja akan meningkat sebesar 0,166 dan demikian pula sebaliknya, dengan asumsi bahwa nilai koefisien variabel yang lain (semua variabel yang mempengaruhi Kinerja Karyawan) adalah tetap atau $\left(\mathrm{a}, \mathrm{x}_{2}=0\right) \mathrm{b}_{2}=$ 0,065 , artinya bahwa Gaji Karyawan mempunyai pengaruh yang positif terhadap Kinerja karyawan, Hal ini menunjukkan bahwa jika penilaian karayawan terhadap Gaji naik sebesar 1 poin maka Kinerja karyawan akan meningkat sebesar 0,065 artinya terjadi hubungan positif antara Gaji dengan Kinerja Karyawan semakin naik Gaji maka semakin meningkat Kinerja Karyawan, dengan asumsi variabel lain yang mempengaruhi dianggap konstan $\left(\mathrm{a}, \mathrm{x}_{1},=0\right)$

Sehingga dapat ditarik kesimpulan bahwa faktor yang paling dominan dalam mendorong Kinerja Karyawan adalah Kedisiplinan dengan koefisien regresi sebesar 0,166 .

Dari hasil uji $\mathrm{t}$ diperoleh $\mathrm{t}$ hitung Kedisiplinan $(3,214)$ dan Gaji Karyawan (2,593). Variabel bebas Kedisiplinan dan Gaji Karyawan mempunyai nilai $\mathrm{t}$ hitung $>\mathrm{t}$ tabel (2.002) maka variabel bebas Kedisiplinan dan Gaji Karyawan mempunyai pengaruh yang signifikan dalam meningkatkan Kinerja Karyawan di UPK Kecamatan Turi.

Daerah Penerimaan dan Penolakan ( Uji t ) Kedisiplinan $\left(\mathrm{X}_{1}\right)$

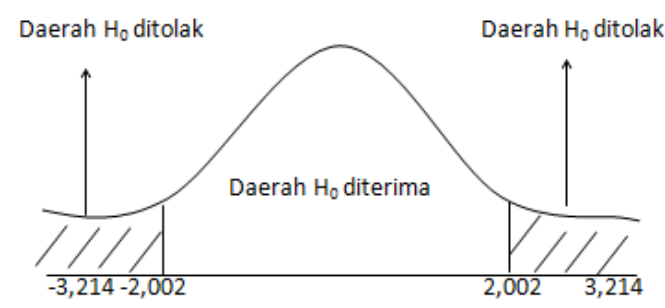

Daerah Penerimaan dan Penolakan ( Uji t ) Gaji Karyawan $\left(\mathrm{X}_{2}\right)$

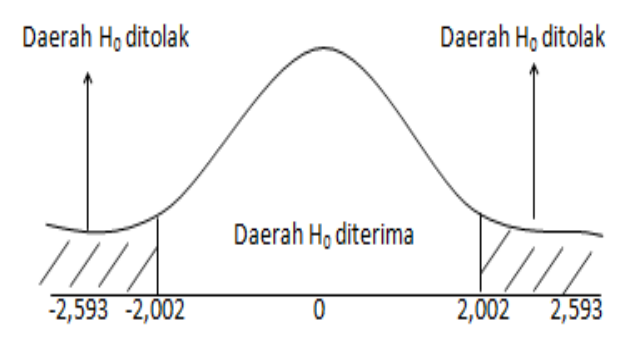


sebesar 3,940 sedangkan $\mathrm{F}$ tabel sebesar 3,15. Artinya F hitung ( $3,940)>\mathrm{F}$ tabel $(3,15)$. Dengan melihat hasil uji $\mathrm{F}$ ini, maka diperoleh asumsi bahwa $\mathrm{H}_{0}$ ditolak dan $\mathrm{H}_{\mathrm{i}}$ diterima, sehingga teruji bahwa terdapat pengaruh yang signifikan antara variabel Kedisiplinan (X1) dan Gaji Karyawan (X2) terhadap kinerja karyawan (Y) di UPK Kecamatan Turi. Hal ini berarti bahwa kinerja karyawan dapat dijelaskan oleh variabel kedisiplinan dan gaji karyawan.

Daerah Penerimaan dan Penolakan $\mathrm{H}_{0}$

( Uji F )

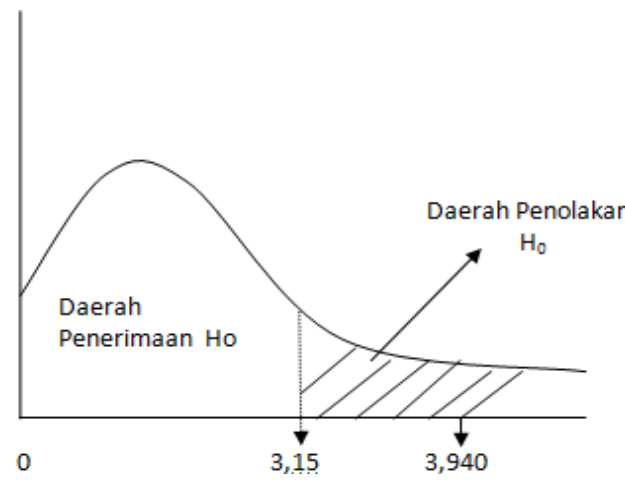

\section{KESIMPULAN}

Berdasarkan hasil analisis yang dilakukan sebagaimana telah dijelaskan dalam bab sebelumnya yang memungkinkan bermanfaat dan dapat dipergunakan sebagai bahan pertimbangan oleh perusahaan dalam masalah yang ada, khususnya yang berhubungan dengan Kinerja Karyawan, maka berdasarkan pada hasil yang di analisis dapat diambil kesimpulan antara lain :

Dari hasil uji $\mathrm{t}$ (parsial) diperoleh nilai t hitung Kedisiplinan $(3,214)$, Gaji Karyawan (2,593). Dengan nilai signifikasi kurang dari 0,05 yaitu secara berurutan masing- masing sebesar Kedisiplinan $(0,230)$, Gaji Karyawan (0,556). Hal ini berarti variabel bebas (Kedisiplinan dan Gaji Karyawan) mempunyai pengaruh secara parsial dalam mempengaruhi Kinerja Karyawan di UPK Kecamatan Turi.

Secara simultan variabel bebas (Kedisiplinan dan Gaji Karyawan) mempunyai pengaruh yang signifikan terhadap Kinerja Karyawan di UPK Kecamatan Turi. Hal ini bisa dibuktikan dengan nilai F hitung sebesar 3,940 dengan tingkat signifikan kurang dari 0,05 yaitu sebesar 0,037. Nilai signifikansi ini menyakinkan bahwa pada model regresi yang dihasilkan terdapat pengaruh yang signifikan. Dapat juga dibandingkan dengan $\mathrm{F}$ tabel. Pada taraf nilai signifikan $\alpha=$ 0,05 dengan $\mathrm{df}_{1}=\mathrm{k}=2 ; \mathrm{df}_{2}=\mathrm{n}-\mathrm{k}-$ $1=60-2-1=57$, maka nilai $\mathrm{F}$ tabel $=3,15$. Artinya $F$ hitung ( $3,940)>F$ tabel $(3,15)$. Dengan melihat hasil uji $F$ ini, maka diperoleh asumsi bahwa $\mathrm{H}_{0}$ ditolak dan $\mathrm{H}_{\mathrm{i}}$ diterima, sehingga teruji bahwa terdapat pengaruh yang signifikan antara variabel Kedisiplinan (X1) dan Gaji Karyawan (X2) terhadap kinerja karyawan (Y) di UPK Kecamatan Turi.

Dari uji regresi linier berganda didapatkan suatu persamaan regresi sebagai berikut: $\mathrm{Y}=9,502+0,166 \mathrm{X}_{1}$ $+0,065 X_{2}$, diperoleh koefisien beta variabel Kedisiplinan sebesar1,58 dan koefisien beta variabel Gaji Karyawan sebesar 0,77. Dengan demikian dapat ditarik kesimpulan bahwa variabel yang paling dominan mempengaruhi Kinerja Karyawan di UPK Kecamatan Turi adalah variabel Kedisiplinan. 


\section{SARAN}

Setelah mengetahui hasil analisis tersebut diatas, masalah yang sedang dihadapi beserta penyebabnya, maka pada kesempatan ini penulis akan kemukakan saransaran yang mungkin bermanfaat atau setidaknya dapat dijadikan pertimbangan di UPK Kecamatan Turi adalah variabel Kedisiplinan dalam rangka mencapai tujuan yang telah direncanakan.

Dengan adanya penelitan ini, kiranya dapat memberikan suatu masukan atau motivasi kepada karyawan-karyawan tentang Pengaruh Kedisiplinan dan Gaji Karyawan terhadap Kinerja Karyawan di UPK Kecamatan Turi.

Instansi harus mampu menerapkan kedisiplinan dan gaji karyawan yang tepat untuk meningkatkan perkembangan demi berlangsungnya kemajuan kinerja karyawan di UPK Kecamatan Turi.

Diharapkan instansi dapat lebih mengajak kepada karyawan untuk disiplin dalam menjalankan kegiatan pelayanan masyarakat. Misalnya intansi lebih memantau perubahan secara terus menerus agar dapat meningkatkan kinerja karyawan.

Demikian simpulan dan saran yang bisa penulis kemukakan dengan harapan bahwa apa yang penulis uraikan dapat membantu dalam memberi masukan berupa empiris yang dapat digunakan untuk memahami Kedisiplinan dan Gaji Karyawan juga dapat mempengaruhi terhadap kinerja karyawan di UPK Kecamatan Turi.

\section{DAFTAR PUSTAKA}

Appley dan Oey Liang Lee. 2010. Pengantar Manajemen. Jakarta : Salemba Empat
Hani Handoko. 2012. Manajemen Personalia \& Sumberdaya Manusia. Yogyakarta : BPFEYogyakarta.

Hamzah B. Uno, M.Pd dan Nina Lamatenggo. 2014. Teori Kinerja dan Pengukurannya. Penerbit : Bumi Aksara.

Malayu S.P. Hasibuan. 2012. Manajemen Sumber Daya Manusia. Jakarta : PT Bumi Aksara.

Riduwan dan Sunarto. 2013. Pengantar Statistik. Bandung: Alfabeta.

Suharsimi Arikunto. 2013. Manajemen Peneltian. Jakarta : Rineka Cipta.

Sadili Samsudin. 2012. Manajemen Sumber Daya Manusia. Penerbit : Pustaka Setia

Sugiyono. 2013. Metode Penelitian Pendidikan Pendekatan Kuantitatif, Kualitatif dan $R \& D$. Bandung : Alfabeta.

Suwatno dan Priansa Donni. 2011. Manajemen Sumber Daya Manusia. Yogyakarta : Penerbit Andi.

Terry, George, R. 2010. Teori Manajemen. Jakarta : Bina Aksara. 